\title{
ВАадимир Цветковић*
}

\section{Извори за изучаване раних екумениских погледа Амфилохија Радовића:Jустин Поповић**}

Почивши митрополит црногорско-приморски Амфилохије Радовић (1938-2020) је свакако изузетна појава у историји Српске православне цркве, како по свом књижевном опусу, ${ }^{1}$ тако и по својој 35 година дугој архипастирској служби. У погледу екуменског деловања постоје супротставњени ставови о његовом ангажману. Са једне стране, иако су му се признавале неке заслуге за улогу коју је имао у православно-католичком дијалогу 2003. године, Радовић је сматран "анти-западњаком" и "српским националистом", што је по аутоматизму значимо и анти-екуменистом. ${ }^{2}$ Са друге стране, Радовић је оптуживан оА неких црквених фракција у Србији, не само Аа је екумениста, већ Аа и је и филопаписта, те Аа заједно са својом колегом са студија у Риму, садашњим Патријархом цариградским Вартоломејом, ради на разбијању православне саборности, и потчињавању православне цркве римском епископу. ${ }^{3}$ Овај рад стога има за ция Аа испита екуменско становиште Амфимохија Радовића, ограничавајући се на период од његових постдипломских студија у Риму 1964. године, па до боравка на Светој Гори 1974. године. То је свакако формативни период за ммадог богослова, када он под Ауховним старатеьством свог духовног оца Јустина Поповића и развија стој став према екуменизму. Пошто је мало његових објавњених радова из тог периода,

\footnotetext{
* Институт за филозофију и Аруштвену теорију, Универзитет у Београду, Србија (vladimir.cvetkovic@ instifdt.bg.ac.rs)

** Ова студија је реализована уз подршку Министарства просвете, науке и технолошког развоја, према Уговору о реализацији и финансирању научноистраживачког рада.

${ }^{1}$ Издавачка кућа Митрополије црногорско приморске Светогора је 2019. године објавима Сабрана дела Амфилохија Радовића у 36 књига.

${ }^{2}$ Buchenau, “From Hot War to Cold Integration?", 65-66.

${ }^{3}$ Петровић, „На кога оА српских теолога је мислио старац Пајсије”.
} 
главни фокус ће бити на његовој преписци са Јустином Поповићем, која је објавьена у другој свесци 23. тома Поповићевих Сабраних дела. Затим ће у центру наше пажње бити издавање књиге Православна Црква и екуменизам Јустина Поповића у Солуну 1974. године на грчком и на српском језику коју као преводилац и уредник потписује Амфикохије Радовић, уз Атанасија Јевтића. На крају ће бити протумачен Радовићев рад из 1972. године „Међуправославни богословски симпозијум, Солун, оА 12-16. септембра 1972. Његов ток уз кратка размишьања“, конфернције износи по први пут и своје виђење екуменизма.

\section{Преписка између Амфилохија (Риста) Радовића и Jустина Поповића}

Ристо (касније монашко име Амфилохије) Радовић постао је духовно чедо Јустина Поповића још као ученик Богословије у Раковици крајем 1950их године. После завршетка богословије Радовић уписује студије теологије на Богословском факултету СПЦ и класичне филологије на Филозофском факултету Универзитета у Београду. После Аипломирања на Богословском факултету 1962. родине, са бцагословом свог духовног оца, Радовић је похађао постдипломске студије прво у Берну, а затим и у Риму. Старокатолички богословски факутет у Берну је свакако средина у којој је Ристо Радовић могао Аа стекне добар увид како сарадња међу црквама, посебно између православних и швајцарских старокалаендараца, који су се током 1870-их одвојили оА Рима због одлука Првог ватиканског концима, функционисала на заједничком фронту отпора папском прозелитизму. Радовић прелази 1964. године у Рим где на Понтификалном оријенталном институту наставља своје последипломске студије. У то време у Ватикану траје Први ватикански концил, који у средиште свог интересовања има и преобликовања односа Римске цркве са остатком хришћанске васељене. Папска енцикмика Unitatis Redintegratio изАата 21. новембра 1964. године, и започиње речима да је обнављање хришћанског јединства један од циьева Аругог ватиканског концица. ${ }^{5}$

Сам Радовићев боравак у Риму у време једног тако великог догађаја сигурно усмерава његов фокус на питања екуменизма и екуменске сарадње међу црквама, посебно што су очекивања од овог концила била велика и по том питању. Радовић се за савет по неколико питања обраћа свом духовном

\footnotetext{
${ }^{4}$ Радовић, „Међуправославни богословски симпозијум“.

${ }^{5}$ Unitatis Redintegratio: "The restoration of unity among all Christians is one of the principal concerns of the Second Vatican Council. Christ the Lord founded one Church and one Church only."
} 
оцу Јустину Поповићу писаним путем. Оригинално писмо поскато Поповићу није објавьено, али је зато објавьен Јустинов одговор Ристу Радовићу од 25. децембра 1964. године, прво насловњен као „Писмо будућем монаху о омимитвьењу ума“ без јасног указивања на реципијента овог писма, ${ }^{6}$ а затим прештампан и у погмавьу Писма Амфимохију у књизи Писма II, која преАставьа 2. свеску 23. тома Јустинових Сабраних дела. ${ }^{7}$

Радовић у свом писму прво обавештава оца Јустина о својој одмуци да прими монашки чин, Аок у Аругом деку свог писма, после упознавања Јустина са својом одлуком да се замонаши, Радовић поставња два питања. Прво питање је о ставу који би православни хришћани требало да имају према неправославном свету, и Аруго о сазивању свеправославног или васењенског сабора Православне цркве, оАносно мишьењу српских богослова о томе.

Ова Ава питања, питање свеправославног или Васеьенског сабора и питање односа православних према неправославним хришћанима, иако на први поглеА немају додирних тачака, овде су дубоко испреплетани. Још оА Родоских свеправославних конференција одржаваних крајем 1950-их и почетком 1960-их, питање одржавања Свеправославног сабора је тесно било повезано са тражењем одговора како православна црква треба да се односи према неправославним хришћанима и према хришћанском јединству. Римокатоличка цркве, је између осталог, и сазвала Аруги ватикански концил да одговори на ово питање, само из своје перспективе. На питање односа православних према неправоскавнима, Јустин одговара:

Став према ванправославном хришћанском свету. Најпре: утврдити себе умом и срцем и животом у Православьу: у његовим светим тајнама и светим врлинама; на тај начин осаборити себе, свој ум, своје срце, свој живот; живети стално ,' са свима светима', јер се само тако могу познати богочовечанске дубине и висине и ширине свега Христовога: живети 'са свима светима' = мислити 'са свима светима' = осећати 'са свима светима' = молити се 'са свима светима' = фубити 'са свима светима'. Једино се на тај начин осигурава свето и Непогрешиво меримо Истине = Цркве Христове, која је увек Ипостасна Истина Богочовека Христа, не икога Аругога или ичега Аругога: 'пуноћа Онога који све испуњава у свему'.

\footnotetext{
${ }^{6}$ Поповић, „Писмо будућем монаху о омилитвњењу ума“. Прештампано као „Писмо будућем монаху о омилитвњењу ума и Свеправославном сабору“, у: Атанасије Јевтић (прир.), Човек Богочовека Христа -

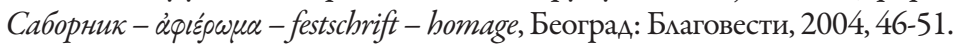

${ }^{7}$ Поповић, Писма II, писмо број 42.

${ }^{8}$ Поповић, „Писмо будућем монаху о омолитвьењу ума“, 300 .
} 
Овде Јустин преокреће перспективу гмедања, те однос православних према неправославнима гради на основу искуства светости. ${ }^{9}$ Тако светитеьство односно светост постаје главни критеријум кроз који се приступа Аругом. Та „изврнута“ перспектива, која за разлику оА Аиректне перспективе и усмерености на себе и остале, јесте поглеА на себе и Аруге кроз зајеАницу „свих светих“ која постоји у есхатолошком смиску. На тај начин се човек, према Јустину, „осаборњује“, односно прикьучује „сабору светих“, а тиме и открива бесконачне дубине и висине Богочовечанског организма. Прижеькивана и очекивана бесконачна и надвремена заједница са Христом и свим светима, тиме постаје мера сваке коначне и временске заједнице овде на земьи, а уједињење са Христом и свим светима постаје крајњи циь којем свако привремено и ограничено уједињење треба да тежи. Тиме Јустин ставња до знања Аа ништа привремено и ововремено не може Аа служи као основа ујеАињења. Јустин то изражава на крају писма следећим речима:

'Екуменизми' су у моди. ${ }^{10}$ Но при томе се, изгледа ми, превиђа оно најбитније: Екуменизам Богочовечанске Истине је срце Богочовечанског $=$ Православног екуменизма, који је увек Ипостас Богочовека Христа, у њеној козмичкој, и свекозмичкој, и надкозмичкој, и свеукупној цемостности, и у земањској историјској конкретности. НикаАа човек, нити ишта човечије, не може бити ни меримо, ни симвоц, ни конкретум екуменизма. Никада човек, ма који човек, већ увек и само Богочовек. Сва је трагедија Запада што је кроз своје сваковрсне хоминизме и хуманизме одбацио Христово Богочовештво. ${ }^{11}$

Према томе, Богочовек Христ је тај стожер на којем се треба градити свако ујеАињење, бимо оно саглеАано: а) у земаьској историјској конкретности, као уједињење хришћана ими шире уједињење ьуди, б) у космичкој перспективи, као уједињење целокупне твари, в) у свекосмичкој перспективи, као уједињење тварног и духовног, односно анђеоског света, и г) наткосмичкој, и свеукупној целостности, као уједињење створене и нестворене

\footnotetext{
9 Овде донекле пратим аргументацију изнету у: Цветковић, Jyстин Поповић, 306-313.

${ }^{10}$ Ова констатација Јустина да су „екуменизми у моди“ превенствено се може односити на чињеницу да од Конференције Централног комитета ССЦ на Родосу 1959. године постоји тенденција међу помесним Православним црквама Аа се прикьуче ССЦ, као и посвећеност Римокатоличке цркве екуменском дијалогу изражена у документу Unitatis Redintegratio из 1964. године. СПЦ је постала пуноправни члан ССЦ на конференцији Централног комитета ССЦ 1965. године у Енугу (Нигерија), када је патријарх српски Герман изабран за једног од копредседника ССЦ.

${ }^{11}$ Поповић, „Писмо будућем монаху о омолитвњењу ума“, 301.
} 
природе, Бога и свега створеног, у Богочовечанској Ипостаси Христа. Ова ширина Јустиновог поглеАа на екуменизам заправо показује да човек, или хуманистичка идеја, била она изражена кроз уједињење у човеку (папи), народном идеалу или Аруштвеном благостању, не може да гарантује ни уједињење човечанства, а камо ми неку ширу космичку или наткосмичку димензију.

Практичан метоА, сматра Јустин, Аа се Аође Ао осаборњавања је кроз утврђивање у Светим тајнама Православне цркве и Светим врлинама. Свете врлине су посебно значајне за Јустина јер на основу њих „човек Аолази и до правимног богопознања и до правимног човекопознања“. ${ }^{2}$

На питање о сазивању Свеправославног сабора, Јустин одговара Аа би такав Сабор морао Аа проистекне, „органски и предањски, из Свеправославног предања Светих Апостола и Светих Отаца“. Према његовом мишьењу, захтеви за одржавање таквог сабора не израстају из православног преАања, те не може бити говора о његовом сазивању. ${ }^{13}$

Ово кратко, али богословски доста садржајно писмо представьа значајан рани документ Јустинових погледа на екуменизам, али и истовремено и поуку свом младом штићенику да је једина основа екуменског сабрања сам Христос. Јустин се овде не ограничава само на међусобно уједињење хришћана, већ укьучује и уједињење све твари, затим уједињење са духовним, анђеоским светом, крунећи се у уједињењу целокупне творевине са Богом, што преАставља најбескрајнију димензију екуменизма. ЈеАан оА закьучака Јустиновог писма је да једино светост, односно искуство светости, обезбеђује ове саборне димензије екуменизма. То има и директне везе са Радовићевом оАкуком да прими монашки постриг, јер као што Јустин прихази екуменизму из перспективе заједнице свих светих, тако прицази у Радовићу из те есхатомошке перспективе. Радовић је, према Јустину, одлуком да се замонаши сагледао себе из исте есхатолошке перспективе, која једино гарантује вечност и бесмртност, исто као што гарантује и истинско зајеАништво и екуменску саборност. Овде видимо Аа изостају Јустинове оштре критике екуменизма по којима ће касније постати познат, и да оно што мхади Радовић оА њега учи је јеАан веома непристрасан, чак и благонакмон однос према екуменизму.

После завршетка магистарских студија у Риму, Радовић је уписао докторске студије на Богословском факултету Универзитета у Атини. Епископ Прокопије Кафалонијски је 1967. године замонашио Радовића, а монашко име Амфилохије је преАложио Јустин Поповић, по Светом Амфимохију Ико-

\footnotetext{
${ }^{12}$ Поповић, Аогматика Православне Цркве, том III, 577-634.

${ }^{13}$ Поповић, „Писмо будућем монаху о омолитвьењу ума“, 300.
} 
нијском, светитеьу из 4. века, чије је житије Јустин тада преводио за своја Жиmија светих. За монаха Амфимохија, монаштво је значило спуштање на нулту тачку егзистенције, одакме Бог покреће из небића у биће. ${ }^{14}$ Годину дана касније, односно 21. јула 1968. године, Амфилохије је рукоположен за јеромонаха.

ОА Јустиновог писма Ристу Радовићу с краја 1964. године до Ава Јустинова писма јеромонаху Амфимохију од 8. августа и 19. новембра 1969. године прошио је нешто мање од пет година, које су испуњене покушајима приближавања Православне и Римокатоличке цркве, и учешћа Православне цркве у екуменским институцијама. Сусрет папе Павла VI и патријарха цариграАског Атинагоре у Јерусалиму у мето 1964. године, као и усвајање документа Unitatis Redintegratio у којем је Римокатоличка црква потврдила посвећеност екуменском дијалогу десио се пре Јустиновог писма Ристу Радовићу из децембра 1964. У међувремену су скинуте обостране анатеме између две цркве 1965. године, СПЦ је исте године постаца чианица Светског савета цркава,а патријарх српски Герман, јеАан оА копредсеАавајућег овог тела, и патријарх Атинагора и папа Павле VI су се 1967. године јавно обавезали на настављање Аијалога између Аве цркве, познатог још и као „дијалог ьубави“, односно „Аијалог у истини“.

Као и у случају претходне преписке између Радовића и Јустина, само су Јустинови одговори на ова Ава писма објавьени, без објавьивања Радовићевих писама, али се јасно види из Јустиновог одговора да је у центру РаАовићевог интересовања овај „Аијалог ьубави“ између католика и православаца. За размику оА претходног писма које има неколико врцо позитивних погледа на екуменизам у његовој космичкој, свекосмичкој и наткосмичкој Аимензији, ова Ава писма су веома критична према екуменском дијалогу замишьеном као „Аијалог ьубави“. Посебно треба истаћи три аргумента који чине оштрицу Јустинове критике.

Прво, Јустин полази оА претпоставке, која по њему стоји у основи екуменизма, Аа „Црква није једна већ многе“. ${ }^{15}$ Иако би се ова теза могла бранити самом чињеницом да фактички постоји велики број организација које себе називају хришћанским црквама, и које желе да превазићу одењеност у односу на остале цркве ујеАињењем у јеАну Цркву, Јустин то не признаје. Он не полази од тако вићене историјске стварности у којој међусобно одењене организације узете зајеАно потенцијално чине јеАну Цркву, већ оА становишта да једност Цркве, као и њена саборност и апостолност извиру из

\footnotetext{
${ }^{14}$ Јевтић, „КаА загрми Ћиров Ристо”.

${ }^{15}$ Поповић, „Писмо 70 [Амфимохију Радовићу од 8. 8. 1969]“, 173.
} 
јеАне Богочовечанске мичности Исуса Христа. ${ }^{16}$ Аоживњај мичности Исуса Христа је истовремено и доживњај Цркве:

Све и сва човеково је и могосно и вечно и блажено у Ипостаси Бога $\Lambda$ госа, и Ипостаси Богочовека. Зато је Он и објавио ову свеблаговест: 'Ја сам Пут, и Истина, и Живот' (Јн. 14, 6). То тројство у Њему је јеАносушно. И то ми ьуди Аоживьујемо као Аичности - сутелесници Његовог Богочовечанског Тема = Цркве. И кроз то доживьујемо Цркву као јеАну и једину, као Богочовечански организам, коме је ГАава Богочовек Христос, и Који се стога ни у ком случају не може делити. Јерес је, свејерес, тврдити да се Црква разделила. Тога никада није било, нити може бити. Отуда савремени екуменизам, овакав какав је, представља и могички и историјски абсурА. ${ }^{17}$

Према томе за Јустина, оне организације које су, заменивши Христа „Аажним Христосима и мажним Месијама“, отпаме оА Цркве, не могу Аа се врате у Цркву кроз Аијалог, већ једино кроз покајање преА Богочовеком који је Црква. ${ }^{18}$ Пошто за Јустина ове организације немају за циь Царство Божије, већ царство земаьско, њихов екуменизам је политикантски, комунистичко-папистичког типа.

Аруго, често се Јустинова критика папства, римокатолицизма или протестантизма узима као противњење екуменизму и критика екуменизма. Међутим, у овом писму Јустин јасно показује да апостолско-светоотачка саборност и слободно и спасоносно исповедање вере у Исуса Христа није само меримо за неправославне хришћане, већ и за Православну цркву:

Кроз екуменизам чисто световна, међународна атеистичко-комунистичка, хоминистичка и богоборна хуманистичка проблематика увукла се у Цркву, и овладала њоме. У комунистичким земьама Православним Црквама комунисти диктирају екуменистичку проблематику и решење њених проблеме. Нити трага оА саборности апостолско-светоотачке, оА слободе у изражавању и исповеАању вере. То је: екуменизам = нихилизам јудинских Никодима, Алексеја, Германа... 'Родоси' ? - Прокомунистичка схватања Православља и проблематике Цркве Православне. ПоА тиранијом руско-српског комунистичког нихили-

\footnotetext{
${ }^{16}$ Поповић, „Писмо 70 [Амфияохију Радовићу]“, 173.

${ }^{17}$ Поповић, „Писмо 71 [Амфимохију Радовићу од 19. 11. 1969]“, 176.

${ }^{18}$ Поповић, „Писмо 70 [Амфияохију Радовићу]“, 173.
} 
зма, и грчког слободарско протестантског рационализма, схоластицизма, анархизма, и атинског авантуризма. Ужурбаност откуда? Комунистичка тиранија и грчка мракоманија - ' $о$ овити у мутној води' ${ }^{19}$

Овде је Јустинова критика екуменизма заправо уперена против екуменске помитике првојерарха Православних цркава, патријарха московског Алексија I и митрополита мењинградског Никодима из Руске цркве, иначе обојице агената совјетске тајне службе КГБ, ${ }^{20}$ патријарха Германа из Српске цркве, патријарха цариградског Атинагоре из Васеьенске патријаршије, агента америчке тајне службе ЦИА, архиепископа Јакова из Грчке архиепископије у Америци, као и неких архијереја у самој Грчкој. У јеАном ранијем писму Атанасију Јевтићу из 1966. године, Јустин назива ове руководиоце Православних цркава игнорантима, макомисленим, јудински макомисленим макејима и самим Јудама, чиме донекме и прави градацију између њихових мотива бављења екуменском политиком. ${ }^{21}$ У истом писму Јевтићу, Јустин сматра свеправославне преАсаборске конференције одржане на Родосу 1963. и 1964. године, и у Београду 1966. године својеврсним „шамарањем распетог на крсту Господа“. 22

Треће, иако Јустин критикује ове свеправославне и екуменске скупове, он не жели да доведе у питање смисленост њиховог одржавања, већ да укаже на њихову бесмисленост уколико су на њима богословске теме замењене социјалним темама. То, према Јустину, као Аиректну последицу има одсуство са тих скупова истакнутих православних светоотачких богослова дијаспоре, попут Георгија ФАоровског, Павла ЕвАокимова, Џона Мајендорфа и Александра Шмемана, које Јустин посебно цени и које назива „апостолима Православьа“. 23 То што су велики православни богослови на овим скуповима замењени првојерарсима и архијерејима као политичким фигурама, ими православним теолозима ограничених интелектуацних могућности и богословске визије представља, према Јустину, издајство православља, јер води опадању богословске, а тиме и апостолско-светоотачке, свести код православних. Зато Јустин назива Православну цркву свог времена катакомбном, зато што су прави сведоци=мартири и исповеАници православља бими

\footnotetext{
${ }^{19}$ Поповић, „Писмо 70 [Амфимохију Радовићу]“, 173-174.

${ }^{20}$ Andrew \& Mitrokhin, The Sword and the Shield, 486-487.

${ }^{21}$ Поповић, „Писмо 91 [Атанасију Јевтићу оА 2. 8. 1966]“, 185.

22 Поповић, „Писмо 91 [Атанасију Јевтићу од 2. 8. 1966]“, 185.

${ }^{23}$ Поповић, „Писмо 70 [Амфияохију Радовићу]“, 174; Поповић, „Писмо 91 [Атанасију Јевтићу од 2. 8. 1966]“, 185.
} 
потиснути у Аруги пцан, Аок су у први пцан избими архијереји политиканти. За Јустина је апостолско-светоотачко богословье бимо арена јединог и правог екуменског сусрета и мера зајеАнице са Богочовеком и свима светима.

Садржај ова Ава писма Амфимохију Радовићу из 1969. године представља критику како екцисијалног плурацитета, односно расцепканости Цркве у мноштво цркава, тако и критику екуменске политике неких православних првојерарха и архијереја. Јустин такође узказује на јеАну опасну појаву у екуменском дијалогу, а то је замена богословских питања социјанним питањима, што за последицу има одсуство великих православних богослова са екуменских скупова, као оних из америчке дијаспоре.

Још јеАно Јустиново писмо треба поменути. Ово писмо од 27. јануара 1971. године није упућено Радовићу већ СА Синоду као одговор на анонимну Аописницу послату СА Синоду о Јустину. Иако писмо није послато Радовићу, не треба сумњати да је Радовић био упознат са Јустиновим ставовима. Јустин у овом писму прво критикује СА Сабор и СиноА СПЦ због прикьучење Светском савету цркава, а затим због толерисања неправославног деловања патријарха цариградског Атинагоре, и нереаговања на одмуку Московске патријаршије о међуопштењу са римокатолицима из 1969. године. Затим се у Аругом дему бави одговорношћу Синода и Сабора за настали раскол у СПЦ (тада актуелан у СПЦ у Северној Америци, а по свему судећи и у југословенској Републици Македонији). На крају, у трећем делу свог писма Јустин критикује полтронско држање Синода и Сабора СПЦ према комунистичкој власти у Југославији. ЗајеАнички именитеь свих ових дешавања Јустин види у идолопоклонству. Тако се, сматра он, праве нови идоли којима се замењује Богочовек Христос и Његова Црква. Ти нови идоли преА којима су СА СиноА и Сабор СПЦ поклекли, бимо пристанком или нечињењем су: Светски савет цркава, римски папизам, неопапизам патријарха цариградског Атинагоре и његов покушај Аа организацијом Свеправославног сабора озваничи међуопштење, оАносно обнавьање евхаристијског јединства између православних и римокатомика, противно Аогматима и канонима Православне цркве, затим властољубље црквене хијерархије које је Аовело Ао раскола у СПЦ, и покоравање епископата комунистичким властима. Тиме се наводна брига самог епископата за Цркву, било кроз покушаје уједињавања са осталим неправославним црквама или разне компромисе по Аругим питањима, према Јустину претвара у идопокцонство краткорочним циьевима и губитак Богочовечанске перспективе. Као и у свим ранијим иступима, мек, ими све-лек који Јустин предиаже је повратак Богочовеку и Његовој Цркви и следовање Светим оцима на том путу. 
Ова четири писма, од тога три Радовићу представљају Јустинове прве осврте на екуменизам, односно екуменске догађаје током 1960-их и раних 1970-их, али истовремено и смернице младом монаху Амфилохију како Аа се постави према овом еклисиолошком питању. Аа интерес Радовића и Атанасија Јевтића, Радовићевог пријатева из студентских дана, прво из Београда, а затим и из Атине, и уједно духовног чеда Јустина Поповића, није јењавао говори како Аања преписка са Јустином, тако и изАавање књиге Јустина Поповића Православна Црква и екуменизам. Издавање овог дела се може сматрати више издавачким подухватом Амфикохија Радовића и Атанасија Јевтића, него самог Јустина, на што упућују детањи из Поповићеве преписке са Радовићем и Јевтићем од 1967. до 1973. године.

\section{Радовић као уредник книге Православна Црква и екуменизам Јустина Поповића}

Јустинова писма својим духовним синовима, пре свих Амфилохију РаАовићу и Атанасију Јевтићу током њихових студија у Атини и Паризу, објеАињена у Аве свеске 23. тома Јустинових Сабраних дела су добар информатор како је до настанка дела Православна Црква и екуменизам заправо дошло. Могло би се рећи да највећу заслугу за писање, а затим и објавьивање овог Аела има сам Радовић, чију молбу Аа се изјасни о екуменизму у јеАној обимнијој студији, Јустин није пренебрегао, као што је то чинио са ранијим молбама те врсте. Писању и објављивању књиге о екуменизму претходимо је Јустиново писање чланка о Аругом ватиканском концицу за издање на немачком језику. ${ }^{24}$ Јустин је добио преко Јевтића, позив једног асистента Теолошког факултета у Атини (чије се име не наводи у писму), Аа прицожи рад о Аругом ватиканском концику. У писму Јевтићу оА 27. фебруара 1967. године, Јустин га обавештава Аа пристаје Аа напише раА, али истовремено изражава бојазан Аа ће његов радикализам одударати од свега у том зборнику. ${ }^{25}$ Већ у писму Јевтићу од 16. марта 1967. године, Јустин саопштава Аа је написао чцанак о Аругом ватиканском концику, и Аа ће му га послати у Атину чим се прекуца. ${ }^{26}$ Уз рад на који Јустин реферише као „Размишьања о Аругом ватиканском

\footnotetext{
${ }^{24}$ Овде пратим аргументацију претходно изнету у Цветковић, Jyстин Поповић, 324-341.

${ }^{25}$ Поповић, „Писмо 98 [Атанасију Јевтићу од 27.2. 1967]“, 201.

${ }^{26}$ Поповић, „Писмо 99 [Атанасију Јевтићу оА 16.3. 1967]“, 202.
} 
конциху“ и који је преведен на немачки, у свом писму Јевтићу од 2. маја 1967. године, шаље исправке немачког превода. ${ }^{27}$ Иако у писму Атанасију Јевтићу оА 4. октобра 1967. године Јустин изражава нестрпьење Аа добије књигу на немачком о Аругом ватиканском концику, ${ }^{28}$ у писму оА 27. маја 1969. године Атанасије Јевтић обавештава Јустина да је немачка издавачка кућа „Хердер“, иначе издавач овог зборника, одбила да штампа његов примог. ${ }^{29} \mathrm{Ha}$ основу исправки немачког језика из Јустиновог писма Атанасију Јевтићу из маја 1967. године може се претпоставити да се ради о чианку који је касније објавьен на српском у Американском Србобрану, часопису српске дијаспоре у Питсбургу (САА), у мају 1969. године поА насловом „О 'непогрешивости' европског човека“, а затим је ушао у Јустинову књигу Православна Црква и екуменизам.

Из преписке Амфимохија Радовића и Атанасије Јевтића са Јустином се може видети њихова жеља и намера да свог духовног оца обавештавају о Аогађајима на екуменским сусретима, као и да га упознају са одговорима православних богослова на те догађаје. Све ово донекле добија и Јустинов коментар. Аијалог између Православне и Римокатоличке цркве је крајем 1960их био фокусиран на Ава питања, питање евхаристије и питање мешовитих бракова. Тако Атанасије Јевтић у свом писму из Атине од 29. фебруара 1969. године шање мишьење неког оца Аанима о „законитости“ мешовитих бракова, које Јустин коментарише оАричући Римокатоличкој цркви оА Првог ватиканског сабора и црквеност и апостолско прејемство. ${ }^{30}$

У свом одговору на писмо Атанасија Јевтића оА 8. августа 1968. године са Свете Горе, тј. из манастира Химандара, и 15. августа исте године из Атине, у којима Атанасије преноси догађаје са Конференције ССЦ из јула 1968. године у Упсали, али доставьа и реферат о екуменизму извесног протојереја Грабеа, ${ }^{31}$ Јустин коментарише одређена питања екуменизма. ${ }^{32}$ Међутим, можАа је најважнији детаь из тог писма Јустиново одбијање момбе светогорског

\footnotetext{
${ }^{27}$ Поповић, „Писмо 100 [Атанасију Јевтићу оА 2. 5. 1967]“, 206.

${ }^{28}$ Поповић, , „Писмо 103 [Атанасију Јевтићу оА 4. 10. 1967]“, 217-218.

29 Јевтић, „Писмо 184 [Јустину Поповићу оА 23. 4. 1969]“, 353. ОАговор на Јевтићево писмо је: Поповић, „Писмо 123 [Атанасију Јевтићу од 27. маја 1968]“, 258.

${ }^{30}$ Поповић, „Писмо 107 [Атанасију Јевтићу од 29. 2. 1968]“, 353.

${ }^{31}$ Овде може бити речи о једном оА Авојице Грабеа који су били у контакту са Јустином или његовим духовним чедима. ЈеАан је Јуриј Павлович Грабе, Јустинов познаник из Сремских Карловаца, и каснији епископ флоридски Руске заграничне цркве, а други је Алексеј Григориевич Грабе, архимандрит, клирик Руске заграничне цркве и управник Руске црквене мисије у Јерусалиму оА 1968. године.

${ }^{32}$ Поповић, „Писмо 114 [Атанасију Јевтићу од 20. 8. 1968]“, 239-241.
} 
монаха старца Никанора (Савића) Химандарца, да због рада на трећем тому своје Аогматике напише књигу против мажног екуменизма. ${ }^{33}$ Тада се можда први пут јавља идеја да би Јустин могао да изрекне неки јавни суд о екуменизму у форми књиге или дужег чланка. У нареАним писмима Атанасију Јевтићу, Јустин се ими захваьује за послати материјал о екуменизму, као нпр. књигу грчког мекара Александра Камомироса, Against the False Union, ${ }^{34}$ извештај Јоаниса Зизиуласа, каснијег митрополита пергамског Цариградске патријаршије, о Четвртој конференцији ССЦ и Упсами, ${ }^{35}$ посланицу архимандрита Епифанија Теодоропулоса Патријарху цариградском Атинагори (Спиру), чланак Теокмита Светогорца о екуменизму и чланак 'The new Papal credo and Orthodox-Catholic relations' архиепископа тиатирског и Велике Британије Васељенске патријаршије Атинагоре (Коконакиса), ${ }^{36}$ књигу Ханса Кинга [Hans Küng] Infallible? An inquiry, ${ }^{37}$ или коментарише одређене теме које искрсавају у екуменском дијалогу, као што су признање Православне цркве Светих тајни код римокатолика, англиканаца и протестаната, ${ }^{38}$ посланицу митрополита Фикарета (Вознесенског) Православне цркве у Америци (ОСА) архиепископу Грчке архиепископије у Америци, Јакову (Кукузису) ${ }^{39}$ оАлука Московске патријаршије о интеркомјунијону (intercommunion) са Римокатоличком црквом. ${ }^{40}$ Слична је Јустинова преписка и са Амфилохијем Радовићем коме ими захвањују на послатом материјалу, нпр. чцанку грчког архиманрита Илије Мастројанопулоса написаном као одговор на „дијалог ьубави“ патријарха Атинагоре, ${ }^{41}$ или пак коментарише одређене екуменске догађаје, као чињеницу да је митрополит града Елефтеруполеоса Амвросије престао да помиње патријарха Атинагору ${ }^{42}$ или несторијанство „међуцрквеног екуменизма“ митрополита халкидонског Мелитона. ${ }^{43}$ Нарочито је важно истаћи да Јустин у једном оА писама Радовићу из 1970. године износи Аа Грчка православна црк-

\footnotetext{
33 Поповић, „Писмо 114 [Атанасију Јевтићу од 20. 8. 1968]“, 239-240.

${ }^{34}$ Поповић,, „Аописница 6 [Атанасију Јевтићу од 7.9. 1968]“, 241.

35 Поповић, „Писмо 115 [Атанасију Јевтићу од 24. 9. 1968]“, 244.

${ }^{36}$ Поповић, „Писмо 129 [Атанасију Јевтићу преА Божић 1969]“, 288-290.

${ }^{37}$ Поповић, „Писмо 142 [Атанасију Јевтићу преА Божић 1969], 269.

38 Поповић, „Писмо 121 [Атанасију Јевтићу оА 21.3. 1969]“, 255.

${ }^{39}$ Поповић, „Писмо 123 [Атанасију Јевтићу оА 27. 5. 1968]“, 258.

${ }^{40}$ Поповић, „Писмо 131 [Атанасију Јевтићу од 27. фебруара 1969]“, 273.

${ }^{41}$ Поповић, „Писмо 70 [Амфимохију Радовићу од 8. 8. 1969]“, 173.

42 Поповић, „Писмо 75 [Амфимохију Радовићу од 16.4. 1970]“, 185.

${ }^{43}$ Поповић, „Писмо 78 [Амфимохију Радовићу од 10. 6. 1970]“, 191.
} 
ва, која је по њему „једина у слободи“, има највећу одговорност „да позове све помесне цркве на саборни и саборски отпор јудинским изАајствима Авојице безумних патријараха“, патријарха цариградског Атинагоре и патријарха московског Алексеја. ${ }^{44}$ Могло би се рећи да је бимо некомико мичних елемената који су утицали да Јустин оАлучи да напише књигу или чланак о екуменизму. То је најпре поменута момба старца Никанора Химандарца из 1967. године Аа напише такво дело, затим одбијање издавачке куће „Хердер“ да се његова критика Аругог ватиканског концила уврсти у зборник о православној рецепцији овог сабора на немачком језику, стално извештавање његове духовне Аеце о екуменским догађајима и објавьеној митератури у вези са екуменизмом, и њихово, посебно Радовићево, инсистирање да Јустин напише студију о екуменизму. ПореА позива Јустину, млади грчки и српски теолози из Атине послали су и једно писмо на адресе еминентних православних теолога, Георгија Фцоровског и Аумитруа Станолоја, са молбом да се и они изјасне о екуменској политици Православне цркве и екуменизму самом. ${ }^{45}$ Радовић, који је први потписани, је то „саборно“ писмо грчких и српских богослова послао и самом Јустину, замоливши га, сада не само у своје иично име, већ и у име потписника, Аа напише чцанак ими књигу о екуменизму. ${ }^{46}$ Иако је Јустин у то време радио на трећем тому своје Аогматике, он се прихватио тог посла и замолио и Радовића и Јевтића да му пошаьу приручник о екуменизму на било ком језику, са информацијама о стварностима, принципима, тенденцијама и намерама екуменизма. $^{47}$

Ауги низ година је књига Православна Црква и екуменизам узимана као једини и изразити Јустинов став према екуменизму. Као што сам Јустин каже у предговору овом Аелу, да бисмо разумели шта „је екуменизам у свом корену и пракорену, у својој суштини и прасуштини, у својим стварностима и тежњама, најбоље ће се видети, ако га огледамо у огледаму Једине Истини-

\footnotetext{
${ }^{44}$ Поповић, „Писмо 75 [Амфилохију Радовићу од 16.4. 1970]“, 185.

${ }^{45}$ Копија писма на грчком језику (без датума) које између осталих потписују и Амфилохије Радовић и Артемије Радосављевић налази се у Архиви Георгија Фцоровског у Принстону (кутија 20, фасцикла 9). Видети: Georges Florovsky Papers, C0586, Manuscripts Division, Department of Rare Books and Special Collections, Princeton University Library. Јустин помиње то писмо у својим писмима Атанасију Јевтићу оА 29. 6. 1971. године (у: Преподобни Отац Јустин, Писма I, писмо 145, 292-293) и Амфимохију Радовићу од 29. 6. 1971. године (у: Преподобни Отац Јустин, Писма II, писмо 86, 209).

${ }^{46}$ Поповић, „Писмо 86 [Амфимохију Радовићу од 29. 6. 1971. године]“, 209.

47 Поповић, „Писмо 145 [Атанасију Јевтићу оА 29. 6. 1971. године]“, 292; Поповић, „Писмо 86 [Амфимохију Радовићу од 29. 6. 1971. године]“, 209.
} 
те Цркве Христове“. ${ }^{48}$ На основу тога књига је подењена на два дела: први Аео измаже православно учење о Цркви, а Аруги се бави темом екуменизма. Међутим, сваки иоле бољи познавацац Јустиновог дема може се изненадити садржајем ове књиге. Оно што изненађује је да је она у великој мери заснована на претходним Јустиновим списима, писаним за Аруга издања и са Аругачијом сврхом, на шта већ указује Атанасије Јевтић. Иако је ова књига донекле и могла Аа служи као значајан увид у Јустинову еклисиологију, она је то престала издањем трећег тома његове Православне философије Истине тј. Аогматике, посвећене искьучиво учењу о Цркви. ${ }^{49}$

Аруги део дела Православна Црква и екуменизам, посвећен теми екуменизма, заправо представьа нека измењена поглавьа Јустинове књиге Светосавље као философија живота из 1953. године. Материјал написан на саму тему екуменизма у Јустиновом позном периоду чини не више оА Авадесетак страница, у који улазе поглавье „Човек или Богочовек“, краћи део поглавља „Хуманистички екуменизам“, и закьучак „Измазак из свих безизмаза“. Међутим, ни текст за претпоследње поглавње, „Човек или Богочовек“, није писан за ову књигу, већ је као чланак „О 'непогрешивости’ европског човека“ написан неколико година раније и објавьен на српском језику у Американском Cрбобрану, часопису српске дијаспоре у Питсбургу (САА), у мају 1969. године. Исте године овај чманак је објавьен на грчком језику, заједно са неким ранијим чианцима у књизи Човек и Богочовек. Студије о православној теологији у Атини.

На питање зашто се Јустин одлучује Аа уместо новог, за ту сврху писаног материјала, посегне за списима писаним и до четири деценије раније може као одговор послужити оно што пише у писму Атанасију Јевтићу:

'Књижицу' о Екуменизму заврших пре неки дан. Сада се прекуцава. Нисам могао да избегнем опширност. Имао сам у виду европско гордоумье. Зато сам силазио у његово демонско подземње, где су му главни црни извори. То сам урадио зато што Европу издавна осећам и знам као такву. У њој скоро потпуно одсуствује осећање греховности и еванђелске одговорности. А света је и свеистинита апостолско-светоотачка православна истина ' $\mathrm{Ca}$ моосуда је почетак спасења'. Европи оА свег срца молитвено желим Аа ту истину што пре осети и доживи, и тако васкрсне себе из свих својих гробова. ${ }^{50}$ Критика екуменизма за Јустина није ништа више оА критике хумани-

\footnotetext{
${ }^{48}$ Поповић, Православна Црква и екуменизам, 9.

${ }^{49}$ Јевтић, „Бемешка уз Записе Оца Јустина“, 33, н. 30.

${ }^{50}$ Поповић, „Писмо 146 [Атанасију Јевтићу од 3. 3. 1972]“, 295.
} 
зма, јер екуменизам је за њега последњи изданак и последња фаза европског хуманизма у којој се човечанство ујеАињује религијски, али на секуларним и хуманистичким основама.

Могло би се Аање поставити питање сврхе издавања овог дела, као и питање саме његове структуре. У великој мери послеАња поглавьа овог Аела могу Аати одговор на ово питање. Књига је, као што се може видети из њеног Аругог Аела, односно из за ту прилику написаних редова, крајње критична према екуменизму, бимо да је он виђен као „дијалог ьубави“ православних са римокатолицима, било као институционацно учешће помесних Православних цркава у ССЦ.

Књига је преведена и објавьена на грчком зато што су једине Аве зАраве снаге по Јустину, које су се могле супротставити екуменском тренду - православна теолошка дијаспора и Грчка православне црква. Пошто су преАставници богословске дијаспоре попут ФАоровског, Шмемана ими МајенАорфа све чешће спречавани да учествују у екуменским скуповима, Јустин се на наговор својих духовних чеда у Атини, окреће Грчкој православној цркви. Грчка црква је бима за Јустина једина која је слободна и способна да се супротстави „самоубимачки површној и издајнички неозбиьној“51 екуменској Аелатности патријарха Атинагоре ${ }^{52}$ (који иначе умире 7. јуна 1972. године, само некомико месеци по завршетку књиге). ${ }^{53}$ Књигу Православна Црква и екуменизам објавио је на грчком језику (и на српском са кога је преведена) српски манастир Химандар 1974. године у Солуну. Можда је смрт патријарха Атинагоре донекме и утицаца да се раА на преводу књиге успори, јер његовом смрћу нестао је главни носимац те политике, али не и прекине, јер је и даье постојаца опасност да ће Атинагорин наследник на царигардском трону, патријарх Аимитрије Пападопулос, наставити стопама свог претходника.

Књига је упућена грчкој црквеној јавности. Иако у свом првом делу садржи изводе из трећег тома Аогматике, књига није академска, ими богословска у ужем смислу те речи. Може се видети по стилу и аргументацији Аа она није намењена ужем кругу професионацних теолога, јер не задовољава академске критеријуме. Она је, нарочито у Аругом, полемичном Аелу, на-

\footnotetext{
${ }^{51}$ Поповић, Јустин, „ОАговор на Анонимну дописницу“, у: Преподобни отац Јустин, Сетве и жетве. Члании и матьи списи, Београд: Наследници Оца Јустина и Манастир Ћелије код Вањева, 2007, 628-646: 633.

52 Поповић, „Писмо 75 [Амфилохију Радовићу од 16.4. 1970]“, 185.

${ }^{53}$ Књига је завршена почетком марта 1972. године. Види: Поповић, „Писмо 146 [Атанасију Јевтићу OA 3.3. 1972]“, 295 .
} 
мењена широј црквеној јавности. То се може видети по фигурама и језику које Јустин користи, као нпр. правњење опозиције између Бога и ђавола (као „бога овога света“ сходно 2. Кор. 4, 4), који су главни гносеолошки чиниоци у фимософији по Богочовеку и њој супротставњеној фимософији по човеку. ${ }^{54}$

Јустин уместо свог познатог филигранског богословског језика овде слика у грубим потезима, сводећи сопствени колоритни појмовник на црно-белу палету. Тако нпр. суптилност са којом у Филособским урвинама или Светосавьу као философији живота прилази модерној космологији и научним резултатима Макса Пианка, Алберта Ајнштајна, ЕАвина Хабла и Вернера Хајзенберга, синтетишући науку са религијом, ${ }^{55}$ у деку Православна Црква и екуменизам прераста у радикализам којим он нпр. супротставьа вечног Бога и бесмртну душу Ајнштајновој теорији релативитета, сада представьеној као завршна и збирна резултанта европског хуманизма. ${ }^{56}$ Управо Јустинови ставови изнети на овако радикацан начин и одвцаче пажњу читаоцима и тумачима овог Аела, што их онемогућава Аа крену Аање и запитају се о историјској позаАини и пишчевим мотивима као контексту у којем је књига настала. Аиректна последица таквог читања без интереса за контекст је Аа читаоци тумачећи је или партизански устају у одбрану у књизи изнетих ставова поистовећујући се са њима, или се пак идеолошки дистанцирају оА њих, устајући у одбрану хуманизма и просветитеьства као модерних тековина Европе. ${ }^{57}$

Самим декларативним опредевењем читаоца за Богочовека и против њему супротставњене хуманистичке Европе, или обрнуто, за хуманистичку Европу и против Православне цркве, остварен је циь писања овог дела, а то је да се идентитетске зајеАнице учврсте у својим вредностима. Претпоставка Јустина и његових ученика да ће грчка црквена јавност устати против овакве врсте екуменизма који, сматрају они, иструментализује Православну цркву зарад хуманистичких и секуларних цињева њених поглавара, показала се тачном.

Без обзира што сам саАржај књиге у већини случајева представља претходно објавьене или необјавьене списе писане са другом сврхом, он ипак успешно преноси Јустинову критику екуменизма као изданка европског хуманизма. Међутим, сама чињеница Аа Јустин скоро ништа ново није написао за ово издање, и да је то више био приређивачки и преводилачки раА

\footnotetext{
${ }^{54}$ Поповић, Православна Црква и екуменизам, 116.

${ }^{55}$ Аубардић, Јустин Ћелијски и Енглеска, 73.

${ }^{56}$ Поповић, Православна Црква и екуменизам, 85.

57 Пример скорије критике овог Јустиновог дема са хуманистичких и просветотевских позиција је у: Čolović, ,Justinovac na I...
} 
његових ученика, Амфимохија Радовића и Атанасија Јевтића, говори да су преводиоци били заинтересованији Аа се богословски ауторитет Јустина Поповића, као и поштовање које је он уживао у грчким црквеним и теолошким круговима, искористи за преиспитивање политике према екуменизму православне цркве. Обојица су годинама показивали велико интересовање за питање екуменизма. Низ њихових овде цитираних писама Јустину, али и Аругим православним теолозима, попут Георгија ФАоровског и Аумитруа Станилоја говоре томе у примог. ${ }^{58}$ Јустин је раду на овом делу посветио нешто мање оА три месеца и то оА краја новембра $1971 .{ }^{59}$ Ао краја фебруара 1972. године, ${ }^{60}$ журећи Аа се врати свом раду на Догматици. У том тромесечном периоду је саставио текст оА 113 куцаних страница, ${ }^{61}$ чија су Ава примерка послата 13. марта 1972. године јеромонаху Атанасију Јевтићу у Париз, и јеромонаху Амфикохију Радовићу у Атину.

Радовић је до пролећа 1973. године био у Атини, где је радио на свом Аокторату, Аа би после тога прешао на Свету Гору, где је остао наредних гоАину Аана. Журило се Аа се књига што пре објави на грчком, Аа би се, према заједничком мишьењу, донекле супротставила „пожару антиправославног екуменизма“ који је захватио грчку цркву. ${ }^{62}$

Постоје најмање Ава разцога зашто је ову књигу 1974. године издао српски светогорски манастир Химандар. Први је свакако боравак Амфилохија на Светој Гори, те могућност Аа са манастиром Химандар конкретно Аоговори штампање књиге на грчком и српском језику, а Аруги је ранији позив старца Никанора Химандарца Јустину да напише књигу против екуменизма са жеьом да се она објави управо у манастиру Химандар. ${ }^{63}$ У крајњој цинији, и саме речи Атанасија Јевтића Аа је Аемо скмопьено на брзину од још

58 Писмо Атанасија Јевтића Георгију ФАоровском писано на Педесетницу 1971. године (кутија 12, фасцикла 13), као и писмо Амфилохија Радовића и Артемија Радосавьевића Фцоровском (без Аатума, кутија 20, фасцикма 9). Атанасије Јевтић помиње у истом писму да се он већ обраћао Аумитру Станияоју по питању екуменизма. Писма се налазе у Архиви Георгија ФАоровског (Georges Florovsky Papers), C0586, Manuscripts Division, Department of Rare Books and Special Collections, Princeton University Library.

59 Види: Поповић, „Писмо 88 [Амфимохију Радовићу од 13. 11. 1971]“, 212. У овом писму Јустин обавештава Амфимохија Аа о екуменизму још није почео писати, јер ужурбано ради на Житијима Светих, и да планира Аа се након тога прихвати писања о екуменизму.

${ }^{60}$ Види: Поповић, „Писмо 146 [Атанасију Јевтићу од 3. марта 1972]“, 295. Овде Јустин извештава Атанасија Аа је „књижицу“ о екуменизму завршио пре неки дан.

${ }^{61}$ Поповић, „Писмо 92 [Амфимохију Радовићу од 13. 11. 1972]“, 220.

${ }^{62}$ Поповић, „Писмо 98 [Амфимохију Радовићу од 30. 10. 1973]“, 235.

${ }^{63}$ Поповић, „Писмо 114 [Атанасију Јевтићу од 20. августа 1968]“, 239-240. 
недовршених рукописа, ${ }^{64}$ указују да је књига бима више пројекат Јустинових ученика, него самог Јустина. Томе иде у примог и Јустинова молба Атанасију Јевтићу Аа он и његова атинска браћа рукопис књиге критички читају и цене, те Аа додају и одузимају шта мисле Аа треба, уз констатацију да ће им због опширности рукописа превођење са српског на грчки одузети доста времена. ${ }^{65}$ На крају Јустин додаје да ће, и ако не буде дошло до превођења књиге на грчки, то бити мање бриге и муке за његова духовна чеда, што показује да се он на само писање ове књиге одлучио више по момби својих ученика, него што је то био његов наум. Сама структура књиге и избор текстова су били Јустинови, о чему сведочи његов познати метод просуђивања свих дематности хришћана на основу мера утврђених у вековном искуству Цркве.

ОА марта 1972. године Радовић ће паралелно радити на превођењу књиге Православна Црква и екуменизам и на изради своје дисертације о Светом Григорију Палами. Средином септембра исте године ће посетити Солун ради учешћа на међуправославном богословском симпосиону које је био посвећен теми предања. Радовић ће написати детаљни извештај са ове конференције, који не само Аа преАставља јеАан оА његових најранијих радова, већ истовремено показује његово становиште према екуменизму.

\section{„Међуправославни богословски симпозијум, Солун, од 12-16. септембра 1972. Његов ток уз кратка размишььға“"}

Овај рад, као што је речено, представьа детаљан Радовићев извештај са међународне православне богословске конференције одржане у Солуну од 12-16. септембра 1972. године, на тему „Предање Православне Цркве и захтеви савременог света“. Из самог Радовићевог извештаја се може видети Аа је конференција била подењена у неколико тематских сесија, почев оА сесије посвећене питањима предања, филетизма и организације Великог сабора православне цркве, преко сесија на теме прилагођавања Цркве свету, васеьенскости и помесности Цркве, закьучно са сесијама посвећеним темама Православне Цркве и екуменизма и богослужења и савременог света. Међутим, иако се тема екуменизма појавьује тек последњих дана симписиона, она се провцачи и кроз остале теме и Радовић јој оА почетка посвећује пажњу.

\footnotetext{
${ }^{64}$ Јевтић, „Православље и екуменизам“, 204, н. 12; Јевтић, „Белешка уз Записе Оца Јустина“, 33, н. 30.

${ }^{65}$ Поповић, „Писмо 146 [Атанасију Јевтићу од 3. марта 1972]“, 295.
} 
САично свом учитељу Јустину, Радовић према екуменизму заузима прво позитиван став, али он појам екуменизма своди на свеправославни екуменизам, који се по њему, као потреба рађа из самог срца Цркве и разоткрива њено органско и унутрашње јединство. ${ }^{66}$ Радовић верно преноси садржаје појединачних излагања, као и дискусију измагача са десет православних богословских факултета, укьучујући и познате богослове попут Александра Шмемана и Аумитруа Станимоја. Истовремено Радовић даје своје коментаре по одређеним темама које откривају његово становиште. ЈеАна оА првих тема где се види Јустинов утицај на Радовића, тиче се организације великог Сабора православне цркве, за који се залагала Цариградска патријаршија. Уз осврт на раА митрополита Хризостома мирског из Цариградске патријаршије, Радовић понавьа три питања на које је указивао и његов духовни отац: могућност сазивања великог сабора са обзиром на прилике у којима се православна црква налази, однос између каталога тема и предања Цркве и питање "Аухоцентричне" екмисиологије. ${ }^{67}$ Наиме, Радовић дели Јустинов став Аа због прилика у којима се православна црква налази, нарочито у комунистичким земьама где је деловање ограничено и строго контролисано оА власти, нису се стекли услови за сазивање сабора. Такође, списак тема који се помиње, по Радовићу који ту следи Јустина, осликава више неуспему копију Аругог ватиканскох концила и екуменских скупова, него што извире из предања Цркве и предањског начина мишьења. На крају, Радовић доводи у питање „Аухоцентричну“ еклисиологију заступану оА представника Цариградске патријаршије, којој Православње треба са се нуждава. Остаје недоречено зашто је Аухоцентична еклисиологија на Радовићевој мети, али могу се претпоставити Ава контекста који он критикује. Први је Аа је духоцентрична еклисиологија одвојена од христоцентричне еклисиологије. За Јустина, а претпостављамо и за Радовића, Црква је тело Христово, и она нема сопствену ипосатас већ је Христова ипосатас истовремено и ипостас Цркве, тако Аа у основи сваке еклисиологије стоји Христос. Такође, Аух Свети је Аух Христов и ништа се не дешава у Цркви Аугом Светим, а Аа у то нису укьучени и Отац и Син. За Радовића, који је тих година радио на докторској тези Тајна Свете Тројице по Светом Григорију Палами, ${ }^{68}$ јасно је Аа у паламитском богословьу о енергијама нема засебнох мичних енергија, већ све, што је и Јустин често наглашавао, полази оА Оца, кроз Сина и с(а)вршава се Ауху Светом.

\footnotetext{
${ }^{66}$ Радовић, „Међуправославни богословски симпозијум“, 340.

${ }^{67}$ Радовић, „Међуправославни богословски симпозијум“, 346-347.

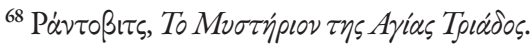


Аруга Аимензије Радовићеве критике може се тицити теолошког тренда коА неких грчких богослова, попут Никоса Нисиотиса, Аа пнеуматологију или пнеуматолошку еклисиологији сматрају јеАинственим и особеним изразом православне цркве, супротстављајући је западној еклисиологији, која је наводно христоцентрична, чак и христомонистичка. ${ }^{69}$

У делу извештаја који се бави темом екуменизма, Радовић тврди, на основу наслова изнетих саопштења, да је проблем односа екуменског покрета и православне цркве поставьен на црквено-политичком, али не и на богословско-еклисиолошком плану. Радовић сматра да су три од четири излагања бима са закьучком Аа је екуменски покрет „потреба времена“, и Аа је Римокатоличка црква „спремна“ на дијалог са православнима. Ти ставови, према Радовићу, не измазе из оквира екуменске политике преминумог Патријаха цариградског Атинагоре. На овом месту Радовић заузима становиште да излагачи, а посебно Андреас Теодору, професор Теолошког факултета Универзитета у Атини, свој став о екуменском покрету не црпу из дубина предања Цркве, већ из „апокалиптичких порука које Аух Свети

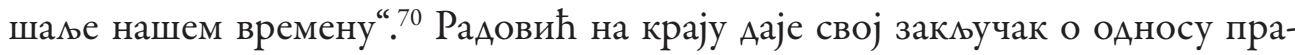
вославне цркве и екуменизма, често подупирући своју позицију, виђењима значајнајних учесника скупа, попут Шмемана и Станимоја. Могу се истаћи Аве ствари у Радовићевој критици овог односа. Прва ствар се по Радовићу тиче пребрзог и недовољно проученог и уравнотеженог става православне цркве Аа уђе у Светски (екуменски) савет цркава. Иако је улазак православне цркве у екуменски дијалог у оквиру ССЦ, у најбољем скучају, био вођен намером Аа се посведочи еванђеьска вера и истина вековима чуване у православној цркви, и тиме исцеле ране западних хришћана, исход је да је она сама попримила секуларни менталитет који влада протестантским заједницама, који се највише огледа у релативизму. Аруга ствар којом се Радовић бави, инспирисана је констатацијом Шмемана о радикалној промени екуменизма, тј. о његовом „трагичном стању““ ${ }^{71}$ У расправи, како Радовић преноси, су се могле јасно видети Аве тенденције тог „новог“екуменизма у односу на стари, против кога устају и Јустин и Радовић. Стари екуменизам је карактерисаца чињеница Аа је он био форум за дијалог хришћанских заједница, првенствено протестантских. Иако је циь био међусобно приближавање видело се Аа и међу протестантским зајеАницама има непревазиђених проблема, а камо-

\footnotetext{
${ }^{69}$ Zizioulas, 'Foreword', viii.

${ }^{70}$ Радовић, „Међуправославни богословски симпозијум“, 357.

${ }^{71}$ Радовић, „Међуправославни богословски симпозијум“, 358.
} 
Аи у односу православне цркве и протестантских заједница. Пракса коју је установио Георгије ФАоровски, бар на Аругој и Трећој конференцији ССЦ, одржаним у Еванстону 1954. године и Њу Аемхију 1961. године, огледама се у томе да су православни делегати ишли са засебним изјавама, у којима се наглашавао особен став православне цркве по одређеним питањима. Таква пракса је прихваћена од осталих, и није доводима у питање дање учешће православних у телима ССЦ. ОА краја 1950-их и избора Архиепископа америчког Јакова Кукузиса за једног од шест са-председника ССЦ, инсистирано је Аа се иде са заједничким изјавама, без истицања особености православних. На Четвртој конференцији Комисије за веру и поредак одржаној у Монтреаму 1963. године, Архиепископ Јаков је подржао доношење документа којим се ССЦ признају атрибути саборности и апостолности, чиме ова организација добија црквени карактер. ${ }^{72}$ Због тога Радовић инсистира на опасностима које се за православье рађају из „органског“ учешћа у ССЦ, ${ }^{73}$ јер се тиме признаје да је православна црква само један од органа, или делова ССЦ као једне мега-цркве. Аа је Архипископ Јаков сматрао ССЦ јеАином институционалном платформом за хришћанско уједињење говори његова изјава са Конференцији Централног комитета Светског савета цркава на Родосу из августа 1959. године Аа дијалог православних и римокатолика може једино Aa cе деси под покровитеьством ССЦ, ими га неће бити. ${ }^{74}$

Аруга опасност које су се Аотакми у Аискусији, а коју Радовић добро преноси, је питање начина „учешћа у болу света“ екуменског покрета. Наиме синтагма „учешће у болу света“ се односи на активни екуменску ангажман у решавању светских проблема попут глади, жеђи, слободе и правде. Како РаАовић преноси, Шмеман је заступао позицију да зајеАничко усредсређивање цркава на ове проблеме и јесте виА секуларизма, јер представьа затварање за онострано и одрицање трансцендентног. ${ }^{75}$

Георгије Фцоровски је такође указивао на напуштање богословских тема оА стране руководства ССЦ и уместо тога његово окретање социјалним темама, као што су проблеми глаАи у свету, мира, атомског наоружања, итА. Тај тренд је, по њему, довео до изразитог јачања Комисије за живот и раА која се бавима практичним питањима хришћанског мимосрђа, упошьавањем вемиког броја особьа и планирањем дамеко већег буџета, на рачун Комисије

\footnotetext{
${ }^{72}$ Baker \& Danckaert, “Georges Florovsky”, 214.

73 Радовић, „Међуправославни богословски симпозијум“, 360.

${ }^{74}$ Baker \& Danckaert, “Georges Florovsky”, 215.

${ }^{75}$ Радовић, „Међуправославни богословски симпозијум“, 359.
} 
за веру и поредак, која се искьучиво бавима теолошким питањима. Последица тога је, према ФАоровском, опадање богословске свести код свих делегата, укьучујући и православне, а крајњи исход је био сличност ССЦ секуларним међународним организацијама попут Уједињених нација, и одумирање његове функције да буде форум за богословски дијалог. ${ }^{76}$

Као одговор на ове опасности Радовић предлаже дубье повезивање савремених проблема православне цркве, попут проблема екуменизма са самим предањем, али не тако као што је бимо до тада Аа проблеми света буду реалнији оА присуства Цркве. За Радовића, богословье разоткривања и позитивног сведочења вековног опита Цркве може Аа одговори на савремена питања једино ако не остане у „сенци света“.77 Тако, према Радовићу, са једне стране стоји православна црква и њена историјска реалност као једино меримо и извор свога постојања и мишьења, а са Аруге стране теологија која савремена питања, попут питања екуменизма, решава без упућености на ово столетно искуство и по секуларним и хуманистичким мерилима.

Радовићев извештај, и у њему изнето становиште о екуменизму, у многоме прати не само принцип и методологију Јустиновог дема Православна Црква и екуменизам, већ и Јустинове позитивне рефмексије о екуменизму изнете како у писму Радовићу 1964. године, тако и у синопсису за књигу Православна Црква и екуменизам из 1971. године, који је објавьен под насловом Белешке о екуменизму 2010. године. Прво, Радовић не сматра Аа је сваки екуменизма мош, и Аа екуменизам који су заступали значајни богослови из дијаспоре, укьучени у екуменске иницијативе током 1950-их и раних 1960-их, попут Георгија ФАоровског, и донекме Аумитру Станимоја представња аутентично сведочење богословља сачуваног у искуству православне цркве. Зато Радовић, као и његов духовни отац Јустин, и говори о православном екуменизму, не као неком конфесионалном идеолошком моделу на који остале хришћанске заједнице треба да се угледају, већ као о вековном предању вере и истине која има највећи саборнизијући и уједињавајућу карактер. Аруго, Радовић као и Јустин на екуменизам гледа као на еклисиолошки проблем, те предлаже да се он решава не неком Цркви страном методологијом већ на основу самог искуста и теологије Цркве. Јустин преАлаже у преАговору свог дема Православна Црква и екуменизам управо да се питање екуменизма огледа у огледалу Једине Истините Цркве Христове. Треће и послеАње, Радовић као и Јустин, повлачи јасну минију раздвајања између православне цркве и њеног предања са јеАне, и

\footnotetext{
${ }^{76}$ Nicoloff \& Yuszczuk, "Interview with Georges Florovsky”, 10.

77 Радовић, „Међуправославни богословски симпозијум“, 366.
} 
савременог света који карактерише секуларизам и хуманизам са Аруге стране. Међутим, за разлику оА Јустина, који корене савременог хуманизма, па тим и хуманистичко-секуларног екуменизма, нахази у папизму и учењу о папској непогрешивости, Радовић ову појаву налази у Византији 14. века. Тако према Радовићу, спорови у 14. веку у Византији између са једне стране прозападно и старојелински настројеног визанијског хуманизма и са Аруге стране у предању Аубоко укорењеног паламитског исихазма, показују да духовна и богословска струјања могу истовремено Аа буду и опасност и искушење, аАи и сведочанство непобедивости Цркве и њене Истине. ${ }^{78}$ Зато богословње, по Радовићу, и треба Аа се темеьи и сведочи искуство Цркве, а не Аа сведочи Цркви стране концепте и решења и да их пројектује на Цркву.

\section{Закључак}

На основу горе изнетог материјала могу се извући неколико важних закьучака, како о Радовићевом раним екуменским ставовима, тако и о прироАи његовог богословског метода и Ауховног опита. Почећемо оА послеАњег, Ауховног опита и узрастања младог монаха. Три гореневедана извора, тј. рана Радовићева преписка са Јустином (1965-1969), његова умога у издавању и уређивању Јустиновог дема Православна Цркве и екуменизам (1970-1971), и извештај са свеправославне конференције у Солуну (1972) преАставьају и три стадијума у Радовићевом духовном узрастању. Рана преписка Јустина и Радовића указује на њихов однос као однос духовног оца и сина, у коме Јустин креирајући Радовићев духовни светонозпор, пружа Радовићу методологији и перспективу из које треба Аа прикази и процењује одређене проблеме, укьучујући ту и проблем односа православне цркве и екуменизма. Та перспектива посматрања је увек кроз призму есхатолошке заједнице свих светих са Христом, као циља свега створеног, која после постаје меримо за све остале зајеАнице. Радовићево уређивање Јустинове књиге о екуменизму, преАставља следећи степен у духовном узрастању и указује на Радовићево усвајање преАања свог духовног оца, које зајеАно са својим духовним братом Атанасијем Јевтићем, он Аање преноси Аа би указао на духовне опасности које екуменизам носи. На крају, Радовићев извештај са солунске конференције осликава како теолошку зрелост, тако у узрасласт младог јеромонаха на нови ступањ Ауховног развоја. Радовић користи Јустинову методологију огледања екуме-

\footnotetext{
${ }^{78}$ Радовић, „Међуправославни богословски симпозијум“, 366.
} 
низма у огмедаму црквеног предања, али не прати у свему Јустинову аргументацију, показујући сопствену богословску инвентивност.

У погледу богословског метода Радовић, слично Јустину, питању екуменизма, али и питању савременог света не прилази са црквено-политичког аспекта, узимајући тренутачно стање неког проблема као једину реалност, већ са богословско-еклисијалног аспекта, тражећи у вековном искуству Цркве неки сличан проблем, као и начине и методе којим се тај проблем решавао. У разматрању неких питања, као нпр. питања хуманизма, одлази и дање оА свог учитеља. Аок Јустин, корен сваког хуманизма нацази у папизму, тј. пребацивању божанских атрибута безгрешности са Бога на човека, што за последицу има затварања човека за трансцендентно, Радовић корене хуманизма нахази у позно-византијској обнови старојеленизма, коју карактерише наглашени рационализам у промишљању духовних појава, стран искуству и преАању Цркве.

На крају, у погмеду екуменског становишта, Радовић као и Јустин, разцикују Ава вида екуменизма, један позитивни који излази из црквеног предања и има највиши степен саборности, и други негативни, који представња претњу црквеној саборности. Први, позитивни екуменизам обојица називају још и православним екуменизмом, и он се огмеда у сведочењу вековног искуства православне Цркве. Православна дијаспора и њени представници, попут ФАоровског, Шмамана и Мајенодорфа су и за Јустина и за Радовића верни представници православног екуменизма у међухришћанском дијалогу. Што се тиче негативног екуменизма он се свакако и за Јустина и за Радовића односи на тзв. „дијалог ьубави“ православних и римокатолика и на учешће православних у ССЦ као некој новој мега-цркви, међутим и овде су њихови фокуси донекле размичити. За Јустина фокус је на папско-протестанском моделу екуменизма, у коме центар црквене саборности није више Христос, као темеь Цркве, већ или папа као „непогрешиви“ "човек, или пак протестански богословски минимализам, као зајеАнички саАржалац свих хришћанских заједница. Код Радовића, фокус није толико на неправославном екуменизму, већ на православној екуменској политици Патријарха цариградског Атинагоре и његових следбеника који зајеАништво са неправославним не граде на основу предања православне цркве, већ на основу потребе и „духа времена“ и ради „учешћа у болу света“, представьајући их као нови призив Светог Ауга и темељ за нову аухоцентричну еклисиологију. 


\section{Библиографија}

Andrew, Christopher and Vasili Mitrokhin, The Sword and the Shield: The Mitrokbin Archive and the Secret History of the KGB, New York: Basic Books, 1999

Baker, Matthew and Seraphim Danckaert, "Georges Florovsky", in: Pantelis Kalaitzidis, Thomas FitzGerald, Cyril Hovorun, Aikaterini Pekridou, Nikolaos Asproulis, Guy Liagre and Dietrich Werner (eds.), Orthodox Handbook on Ecumenism: Resources for Theological Education, Oxford: Oxford University Press, 2014, 211-215.

Buchenau, Klaus, "From Hot War to Cold Integration? Serbian Orthodox Voices on Globalization and the European Union”, in: Victor Roudometof, Alexander Agadjanian and Jerry Pankhurst (eds.), Eastern Orthodoxy in a Global Age Tradition Facesthe Twenty-first Century, Walnut Creek, CA: AltaMira Press, 58-83.

Zizioulas, John, "Foreword”, in: Nikolaos Asproulis and John Chryssavgis (eds.), Theology as Doxology and Dialogue: The Essential Writings of Nikos Nissiotis, Lenham, MD: Lexington Books/ Fortress Academic 2019, vii-viii.

Јевтић, Атанасије (прир.), На богочовечанском путу, БеограА, Манастир Ћелије коА Вањева, 1980 ('2014).

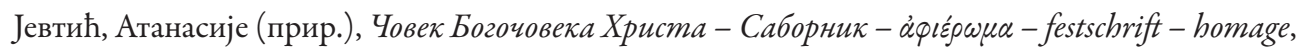
БеограА: БАаговести, 2004.

Јевтић, Атанасије „О екуменизму“, у: Александар Ђаковац (прир.), Православље и екуменизам: зборник текстова, БеограА: Хришћански културни центар, 2005, 195-205.

Јевтић, Атанасије, „Белешка уз Записе Оца Јустина“, у: Свети Ава Јустин, Записи о екуменизму, Манастир Тврдош, 2010, 31-35.

Јевтић, Атанасије, „КаА загрми Ћиров Ристо: Како је Атанасије Јевтић говорио о митрополиту Амфилохију", Sputnik Србија 1.11.2020: https://rs.sputniknews.com/20201101/kadzagrmi-cirov-risto-kako-je-atanasije-jevtic-govorio-o-mitropolitu-amfilohiju-1123711946.html (приступьено 13.9.2021).

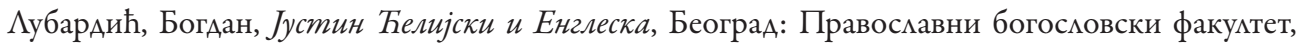
2019.

Петровић, Миодраг М., „На кога оА српских теолога је мислио старац Пајсије каА је рекао ,тај је куса змија'“, Стағе стари: https://stanjestvari.com/2019/07/15/miodrag-petrovic-nakoga-je-mislio-starac-pajsije/ (приступьено 12.9.2021).

Поповић, Јустин, Догматика Православне Цркве, том III, БеограА: Манастир Ћелије код Ваљева, 1978.

Поповић, Јустин, Православна Црква и екуменизам, Света Гора Атонска: Манастир Хияандар, ${ }^{2} 1995$.

Поповић, Јустин, „ОАговор на Анонимну дописницу“, у: Преподобни отац Јустин, Сетве ижетве: Чланщи и мағи списи, БеограА: НаслеАници Оца Јустина и Манастир Ћелије коА Вамева, 2007, 628-646.

Поповић, преподобни Отац Јустин, Писма I (Сабрана дела Светог Јусина Новог у 30 книга, књига 23/1), БеограА: Манастир Ћемије код Вањева, 2020.

Поповић, преподобни Отац Јустин, Писма II (Сабрана дела Светог Јусина Новог у 30 къига, књига 23/2), Београд: Манастир Ћемије код Вањева, 2020.

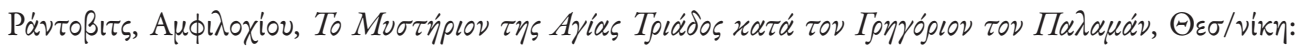

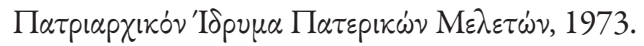


Радовић, Амфилохије, „Међуправославни богословски симпозијум, Солун, од 12-16. септембра 1972. Његов ток уз кратка размишьања“, у: Александар Ђаковац (ур.), Православље и екуменизам: зборник текстова, БеограА: Хришћански културни центар, 2005, 339-368.

Unitatis Redintegratio (https://www.vatican.va/archive/hist_councils/ii_vatican_council /documents/vat-ii_decree_19641121_unitatis-redintegratio_en.html.

Florovsky, Georges, Papers, C0586, Manuscripts Division, Department of Rare Books and Special Collections, Princeton University Library.

Цветковић, ВАадимир, Јустин Поповић: синтеза традиције и иноващије, БеограА: Институт за фимозофију и Аруштвену теорију, 2021.

Čolović, Ivan, „Justinovac na I.,, Peščanik 5. 4. 2021: https://pescanik.net/justinovac-na-i/ (приступьено 7.4.2021.) 